\title{
Acute toxicity test of two pesticides diazinon and deltamethrin on spirlin (Alburnoides bipunctatus) larvae and fingerling
}

\author{
Mohammad Forouhar Vajargah*, Sayede Amene Hossaini and Aliakbar Hedayati
}

Department of Fishery, Faculty of Fisheries and Environment, Gorgan University of Agricultural Science and Natural

Resources, Gorgan, Iran.

Accepted 18 May, 2013

\begin{abstract}
The present research was performed to determine and compare acute toxicity of diazinon and deltamethrin to spirlin larvae and fingerling. Diazinon and deltamethrin are common useful agricultural pesticides. $\mathrm{LC}_{50}$ of $24,48,72$ and $96 \mathrm{~h}$ was attained by probit analysis software SPSS Version 16. Fish samples (21 fish in each test group) were exposed to different concentrations of diazinon and deltamethrin (diazinon: for fingerling between 1 to $20 \mathrm{ppm}$ and larvae 0.25 to $2 \mathrm{ppm}$; deltamethrin: for fingerling between 0.01 to $0.2 \mathrm{ppm}$ and larvae 0.0025 to $0.02 \mathrm{ppm}$ ) for $96 \mathrm{~h}$ and mortality were recorded. The $\mathrm{LC}_{50} 96 \mathrm{~h}$ of diazinon for fingerlings and larvae were 7.88 and 0.69 , respectively. The $\mathrm{LC}_{50} 96 \mathrm{~h}$ of deltamethrin for fingerlings and larvae were 0.27 and $0.006 \mathrm{ppm}$, respectively. According to the results, larvae are more sensitive than fingerlings. In the present study, $\mathbf{L C}_{50}$ values indicated that deltamethrin is more toxic than diazinon to this species.
\end{abstract}

Key words: Diazinon, deltamethrin, lethal toxicity, Alburnoides bipunctatus.

\section{INTRODUCTION}

Fresh water is a valuable resource and the increasing pollution of our rivers and lakes is a cause for alarm. During the last decades, significant amounts of pesticides belonging to the classes of organophosphates have been released into the environment. The use of diazinon and deltamethrin is common to control herbal pests in many agriculture fields that are located in the vicinity of fresh water resources.

Diazinon is an organophosphorus compound with an anticholinesterase mode of action (Tinoco-Ojanguren and Halperin, 1998). It is used extensively to control flies, lice, insect pests of ornamental plants and food crops, as well as nematodes and soil insects in lawns and croplands. Diazinon degrades rapidly in the environment, with halftime persistence usually less than 14 days. But under conditions of low temperature, low moisture, high alkalinity and lack of suitable microbial degraders, diazinon may remain biologically active in soils for 6 months or longer (Eisler, 1986). Because of its aquatic distribution, diazinon affects a wide range of non-target organisms, like invertebrates, mammals, birds and fishes, especially those inhabiting aquatic environment (Burkepile et al., 2000; Hamm and Hinton, 2000).

Deltamethrin is a fourth generation synthetic pyrethroid pesticide (Leahey, 1985). Deltamethrin and other pyrethroids have been found to be extremely toxic to fish (Balint et al., 1995; Datta and Kaviraj, 2003; Delistraty, 2000; Eells et al., 1993; Svobodova et al., 2003; Szegletes et al., 1995; Viran et al., 2003); it had an impact on aquatic herbivorous insects. This impact led to an increase of algae. Aquatic fauna, particularly crustacea, may be affected, but fish are not harmed under normal conditions of use (Worthing, 1983). Fish is one of the important aquatic organism that are important, because of

*Corresponding author. E-mail: Forouhar.eco89@yahoo.com. Tel: +981712220320. Fax:+981714427040. 
Table 1. The mortality rate of $A$. bipunctatus exposed to acute commercial diazinon (21 fish for each concentration).

\begin{tabular}{lccccc}
\hline \multirow{2}{*}{ Group } & \multirow{2}{*}{ Concentration $(\mathbf{p p m})$} & \multicolumn{4}{c}{ No. of mortality } \\
\cline { 3 - 6 } & $\mathbf{2 4} \mathbf{~}$ & $\mathbf{4 8} \mathbf{~}$ & $\mathbf{7 2} \mathbf{~}$ & $\mathbf{9 6} \mathbf{~}$ \\
\hline \multirow{4}{*}{ Fingerling } & 1 & 0 & 0 & 2 & 3 \\
& 5 & 0 & 2 & 5 & 8 \\
& 10 & 2 & 4 & 7 & 12 \\
& 20 & 3 & 8 & 14 & 21 \\
& Control & 0 & 0 & 0 & 0 \\
\multirow{4}{*}{ Larvae } & 0.25 & 0 & 1 & 3 & 5 \\
& 0.5 & 0 & 3 & 7 & 9 \\
& 1 & 2 & 5 & 9 & 14 \\
& 2 & 4 & 9 & 15 & 21 \\
& Control & 0 & 0 & 0 & 0 \\
\hline
\end{tabular}

the economic value and the sensitivity against contaminants, and are used in a wide range for biological assays.

This study was performed to determine toxicity of diazinon and deltamethrin on the spirlin. Its distribution is in Europe and Asia: in France eastward, Black and Azov seas; Caspian basin, upper Volga and from Kura drainage southward to Iranian tributaries of Caspian; widespread in Iran, in Mediterranean, Marmara and Aral basin (Reshetnikov et al., 1997; Kottelat and Freyhof, 2007; Sal'nikov, 1998; Coad, 1981; Bogutskaya, 1997).

Alburnoides bipunctatus inhabit streams and rivers in foothills with well oxygenated, fast-flowing water. All age classes occur in open water of streams and small rivers (Kottelat and Freyhof, 2007). Found also in rivers with very calm waters, are feeds on insect larvae and dead insects as well as on crustaceans and diatoms (Vostradovsky, 1973).

A. bipunctatus was selected for the bioassay experiments, because it is widespread in most part of Europe and Asia and it can be found in Marine-Neritic, Marine-Oceanic, Brackish water and Freshwater.

\section{MATERIALS AND METHODS}

The purpose of this research was to determine the toxicity of diazinon and deltamethrin on $A$. bipunctatus larvae and fingerlings. Lethal experiments were conducted using 125 larvae and 125 fingerling for each of the tested pesticides. Physicochemical properties of water were as follows: $23 \pm 1^{\circ} \mathrm{C}$ temperature, 7 to $9 / 5$ $\mathrm{mg} / \mathrm{L}$ dissolved oxygen, $\mathrm{pH} 6.5$ to 8 and $220 \mathrm{mg} / \mathrm{L}$ total hardness. During the experiment, water was not exchanged. Before the test, fish were fed twice daily with Biomar feed of $2 \%$ body weight.

Concentrations of diazinon were 1, 5, 10, and 20 for fingerlings and $0.25,0.5,1$ and $2 \mathrm{mg} / \mathrm{L}$ for larvae. These concentrations for deltamethrin were $0.01,0.05,0.1$ and 0.2 for fingerling and 0.0025 , $0.005,0.01$ and 0.02 for each pesticide fingerlings and larvae were divided into five groups of 21 separately. So there were four group as follows: fingerlings by diazinon, larvae by diazinon, fingerling by deltamethrin and larvae by deltamethrin. In each group, there were 4 treatments and 1 control. Mortality rates were recorded at time 0 , 24, 48, 72 and $96 \mathrm{~h}$.

Experiments were performed according to the Organization for Economic Co-operation and Development (OECD) standard method (1998), to determine the $\mathrm{LC}_{50} 96 \mathrm{~h}$ of spirlin larvae and fingerlings. Number of dead fish was recorded at time 24, 48, 72, and $96 \mathrm{~h}$. Acute toxicity tests was carried out according to Hotos and Vlahos (2000).

\section{RESULTS}

The mortality of $A$. bipunctatus fingerling and larvae were $1,5,10$, and $20 \mathrm{ppm}$ and $0.25,0.5,1$, and $2 \mathrm{ppm}$ for diazinon doses, respectively. The rates were $0.01,0.02$, 0.10 and $0.20 \mathrm{ppm}$ and $0.0025,0.005,0.01$, and 0.02 ppm for deltamethrin examined during the exposure times at 24, 48, 72 and $96 \mathrm{~h}$ (Tables 1 and 2).

The results of this study indicated that $\mathrm{LC}_{50} 96 \mathrm{~h}$ of diazinon is $7.88 \mathrm{ppm}$ for fingerling and $0.69 \mathrm{ppm}$ for larvae, thus maximum allowable concentration (MAC) value is equal to 0.788 and $0.069 \mathrm{ppm}$, respectively (Tables 3 and 4). As well as for deltamethrin, MAC value for fingerling and larvae is equal to 0.027 and 0.0006 , respectively.

The results indicated that spirlin larvae are more sensitive than fingerlings, exposed to pesticides deltamethrin and diazinon. Moreover, deltamethrin is more toxic to $A$. bipunctatus than diazinon.

\section{DISCUSSION}

Today, diazinon is used extensively by commercial and home applicators in a variety of formulations to control flies, cockroaches, lice on sheep, insect pests of ornamental plants and food crops (especially corn, rice, onions, and sweet potatoes), forage crops such as 
Table 2. The mortality rate of $A$. bipunctatus exposed to acute commercial deltamethrin (21 fish for each concentration).

\begin{tabular}{lccccc}
\hline \multirow{2}{*}{ Group } & \multirow{2}{*}{ Concentration (ppm) } & \multicolumn{5}{c}{ No. of mortality } \\
\cline { 3 - 6 } & $\mathbf{2 4} \mathbf{~}$ & $\mathbf{4 8} \mathbf{~}$ & $\mathbf{7 2} \mathbf{~}$ & $\mathbf{9 6} \mathbf{~}$ \\
\hline \multirow{4}{*}{ Fingerling } & 0.01 & 0 & 0 & 1 & 5 \\
& 0.05 & 0 & 2 & 5 & 8 \\
& 0.1 & 0 & 3 & 8 & 12 \\
& 0.2 & 3 & 8 & 14 & 21 \\
& Control & 0 & 0 & 0 & 0 \\
\multirow{4}{*}{ Larvae } & 0.0025 & 0 & 1 & 2 & 5 \\
& 0.005 & 0 & 2 & 6 & 10 \\
& 0.01 & 1 & 5 & 9 & 15 \\
& 0.02 & 4 & 10 & 16 & 21 \\
& Control & 0 & 0 & 0 & 0 \\
\hline
\end{tabular}

Table 3. Lethal concentrations of diazinon.

\begin{tabular}{|c|c|c|c|c|c|}
\hline \multirow{2}{*}{ Group } & \multirow{2}{*}{ Point } & \multicolumn{4}{|c|}{ Concentration (ppm) } \\
\hline & & $24 \mathrm{~h}$ & $48 \mathrm{~h}$ & $72 \mathrm{~h}$ & $96 \mathrm{~h}$ \\
\hline \multirow{7}{*}{ Fingerling } & $\mathrm{LC}_{1}$ & 2.9 & - & - & - \\
\hline & $\mathrm{LC}_{10}$ & 15.8 & 8.13 & 2.62 & 1.2 \\
\hline & $\mathrm{LC}_{30}$ & 25.2 & 17.8 & 9.66 & 5.15 \\
\hline & $\mathrm{LC}_{50}$ & 31.7 & 22 & 14.5 & 7.88 \\
\hline & $\mathrm{LC}_{70}$ & 38.2 & 27.7 & 19.4 & 10.62 \\
\hline & $\mathrm{LC}_{90}$ & 47.6 & 36 & 26.4 & 14.5 \\
\hline & LC $_{99}$ & 60.5 & 47.7 & 36.1 & 20 \\
\hline \multirow{7}{*}{ Larvae } & $\mathrm{LC}_{1}$ & 0.35 & - & - & - \\
\hline & $\mathrm{LC}_{10}$ & 1.46 & 0.54 & - & - \\
\hline & $\mathrm{LC}_{30}$ & 2.27 & 1.45 & 0.77 & 0.44 \\
\hline & $\mathrm{LC}_{50}$ & 2.83 & 2.08 & 1.28 & 0.69 \\
\hline & $\mathrm{LC}_{70}$ & 3.39 & 2.71 & 1.8 & 0.94 \\
\hline & $\mathrm{LC}_{90}$ & 4.2 & 3.62 & 2.55 & 1.3 \\
\hline & $\mathrm{LC}_{99}$ & 5.31 & 4.88 & 3.58 & 1.8 \\
\hline
\end{tabular}

alfalfa, and nematodes and soil insects in turf, lawns, and croplands (Anon, 1972; Meier et al., 1976; Allison and Hermanutz, 1977; Berg, 1984; Stone and Gradoni, 1985; Eisler, 1986). Organophosphate compounds are generally lipophilic and easily absorbs through the skin, gills and digestive system and pass through blood and brain barrier (Vale, 1998), because the inhibition of acetylcholinesterase activity in fish can cause changes in behavior, severe abnormalities in growth and nutrition, and survival rates of behavioral disorders in their breeding (Dutta and Arends, 2003).

One of the pyrethroids has been found wide acceptability and is extremely used in agriculture and forestry, because of its high activity against a broad spectrum of insect pests (Villarini et al., 1998) such as deltamethrin. However, its effects on nervous, respiratory, and hematological systems in fishes have been reported (Pimpão et al., 2007; Ural and Sağlam, 2005). Therefore, to evaluate the effect of pesticides on aquatic organisms are important.

In this study, fingerlings and larvae were used, because toxins are very influential in the early stages of life, especially during the larval stage, as the effect of deltamethrin on the sensitive early life stages of zebrafish, Brachydanio rerio, were examined by Görge and Nagel (1990). Deltamethrin can be highly toxic to fish. The development of larvae was influenced by deltamethrin. The United States Department of Agriculture (USDA) National Agricultural Pesticide Impact Assessment Program's document reports that deltamethrin has acute 
Table 4. Lethal Concentrations of deltamethrin.

\begin{tabular}{lccccc}
\hline \multirow{2}{*}{ Group } & \multirow{2}{*}{ Point } & \multicolumn{4}{c}{ Concentration (ppm) } \\
\cline { 3 - 6 } & & $\mathbf{2 4} \mathbf{h}$ & $\mathbf{4 8} \mathbf{h}$ & $\mathbf{7 2} \mathbf{~}$ & $\mathbf{9 6} \mathbf{~}$ \\
\hline \multirow{6}{*}{ Fingerling } & LC1 & - & - & - & - \\
& LC10 & 1.34 & 0.07 & - & - \\
& LC30 & 2.75 & 0.74 & 0.25 & - \\
& LC50 & 3.73 & 1.21 & 0.65 & 0.27 \\
& LC70 & 4.71 & 1.67 & 1.06 & 0.63 \\
& LC90 & 6.13 & 2.35 & 1.64 & 1.16 \\
& LC99 & 8.08 & 3.28 & 2.44 & 1.88 \\
& & & & & \\
& LC1 & 0.008 & - & - & - \\
& LC10 & 0.018 & - & 0.002 & 0.0007 \\
& LC30 & 0.025 & 0.011 & 0.008 & 0.004 \\
& LC50 & 0.031 & 0.021 & 0.012 & 0.006 \\
& LC70 & 0.036 & 0.032 & 0.017 & 0.008 \\
& LC90 & 0.043 & 0.047 & 0.023 & 0.012 \\
& LC99 & 0.053 & 0.068 & 0.031 & 0.016 \\
\hline
\end{tabular}

toxicity to fish in laboratory tests to be in the average range $\mathrm{LC}_{50}$ value of 1 to $10 \mu \mathrm{g} / \mathrm{L}$ (Köprücü and Aydın, 2004). According to the results, $L^{2} C_{50} 96 \mathrm{~h}$ of deltamethrin were 0.27 and $0.006 \mathrm{ppm}$ for fingerling and larvae, respectively.

In this study, $\mathrm{LC}_{50} 96 \mathrm{~h}$ of diazinon was 7.88 and 0.69 $\mathrm{ppm}$ for fingerling and larvae, respectively. According to the same research, freshwater teleosts were comparatively resistant to diazinon, with all $\mathrm{LC}_{50} 96 \mathrm{~h}$ values greater than $90 \mu \mathrm{g} / \mathrm{L}$. Sublethal effects were recorded at 0.3 to $3.2 \mu \mathrm{g} / \mathrm{L}$ diazinon and they include reduced emergence of stream insects $(0.3 \mu \mathrm{g} / \mathrm{L})$, reduced fecundity of a marine fish $(0.47 \mu \mathrm{g} / \mathrm{L})$, significant accumulations in freshwater teleosts $(0.55 \mu \mathrm{g} / \mathrm{L})$, potential mutagenicity in a freshwater fish $(1.6 \mu \mathrm{g} / \mathrm{L})$, and spinal deformities in teleosts $(3.2 \mu \mathrm{g} / \mathrm{L})$ (Eisler, 1986). In comparison with other results, $A$. bipunctatus is a semiresistant species against diazinon and it is highly toxic. $A$. bipunctatus and abnormal behaviors observed in fish exposed to acute toxicity, including severe restlessness, anxiety, loss of ability to orient in water, swimming in a semi-circle, and dark body, confirm referred symptoms in previous reports (Pazhand, 1999).

Studies that indicate low level of deltamethrin (0.005 $\mu \mathrm{g} / \mathrm{L}$ ) in the aquatic environment may have a significant effect on carp populations. Being a general toxicant for aquatic life, it should be used with great caution in agriculture to protect natural waters from contamination (Köprücü and Aydın, 2004).

\section{REFERENCES}

Allison DT, Hermanutz RO (1977). Toxicity of diazinon to brook trout and fathead minnows. U.S. Environmental Protection Agency Report, Environmental Research Laboratory. P 69.

Anon (1972). Diazinon insecticide. Tech. Bulletin. CIBA-GEIGY, Agricultural Division Ardsley, New York.

Balint T, Szegletes T, Szegletes ZS, Halasy K, Nemcsok J (1995). Biochemical and subcellular changes in carp exposed to the organophosphorus methidation and the pyrethroid deltamethrin. Aquat. Toxicol. 33 (3-4):279-295.

Berg GL (1984). Farm chemicals handbook. Meister Publ. Co., Willoughby, Ohio. P 501.

Bogutskaya NG (1997). Contribution to the knowledge of leuciscine fishes of Asia Minor. Part 2. An annotated check-list of leuciscine fishes (Leuciscinae, Cyprinidae) of Turkey with descriptions of a new species and two new subspecies. Mitt. Hamb. Zool. Mus. Inst. 94:161-186.

Burkepile DE, Moore MT, Holland MM (2000). The susceptibility of five nontarget organisms to aqueous diazinon exposure. Bull. Environ. Contam. Toxicol. 64:114-121.

Coad BW (1981). Fishes of Afghanistan, an annotated check-list. Publ. Zool. Natl. Mus. Can. 14:23.

Datta M, Kaviraj, A (2003). Acut toxicity of the synthetic pyrethroid deltamethrin to freshwater catfish Clarias gariepinus, Bull. Erviron. Contam. Toxicol. 70 (2):296-299.

Delistraty D (2000). Acute toxicity to rats and trout with a focus on inhalation and aquatic exposures. Ecotoxicol. Environ. Saf. 46:225233.

Dutta HM, Arends, D (2003). Effects of endosulfan on brain acetylcholinesterase activity in juvenile bluegill sunfish. Environ. Res 91:157-162.

Eells JT, Rasmussen JL, Bandettini PA, Propp JM (1993). Differences in the neuroexcitatory actions of pyrethroid insecticides and sodium channel-specific neurotoxins in rat and trout brain synaptosomes, Toxicol. Appl. Pharmacol. 123:107-119.

Eisler R (1986). Diazinon hazards to Fish, Wildlife and Invertebrates: A synoptic review. Patuxent Wildlife Research Center. U.S. Fish and Wildlife Service, Biol. Rep. 85(1.9):25.

Görge G, Nagel R (1990). Toxicity of lindane, atrazine and deltamethrin to early life stages of zebrafish (Brachydanio rerio), Ecotoxicol. Environ. Saf. 20:246-255.

Hamm JT, Hinton DE (2000). The role of development and duration of exposure to the embryotoxicity of diazinon. Aquat. Toxicol. 48:403418. 
Kottelat M, Freyhof J (2007). Handbook of European freshwater fishes. Public. Kottelat. Cornol., Switzerland. pp. 646.

Köprücü K, Aydın R (2004). The toxic effects of pyrethroid deltamethrin on the common carp (Cyprinus carpio L.) embryos and larvae. Pesticide Biochem. Physiol. J. 80:47-53

Leahey JP (1985). The Pyrethroid Insecticides. Taylor and Francis, London. P 180.

Meier EP, Warner MC, Dennis WH, Randall WF, Miller TA (1976). Chemical degradation of military standard formulations of organophosphate and carbamate pesticides. I. Chemical hydrolysis of diazinon. U.S. Army Medical and Bioengineering Research and Development Laboratory, Fort Detrick. Technical Report 7611, pp. 32.

Pazhand Z (1999). Determination of lethal concentrations $L C_{50} 96 \mathrm{~h}$ of the pesticides butachlor and diazinon on Acipenseridae fry ( $A$. persicus and A. stellatus). M.Sc Thesis, Lahijan Azad University. pp. 9-20.

Pimpão C, Zampronio AR, Silva de Assis HC (2007). Effects of sublethal doses of deltamethrin on hematological parameters and enzymatic activity in Ancistrus multispinis (Pisces, Teleostei). Pest. Biochem. Physiol. 88:122-127.

Reshetnikov YS, Bogutskaya NG, Vasil'eva ED, Dorofeeva EA, Naseka AM, Popova OA, Savvaitova KA, Sideleva VG, Sokolov LI (1997). An annotated check-list of the freshwater fishes of Russia. J. Ichthyol. 37(9):687-736.

Sal'nikov VB (1998). Anthropogenic migration of fish in Turkmenistan. J. Ichthyol. 38(8):591-602.

Stone WB, Gradoni PB (1985). Wildlife mortality related to use of the pesticide diazinon. Northeast Environ. Sci. 4:30-38.

Svobodova Z, Luskova V, Drastichova MJ, Svoboda M, Labek V (2003). Effect of deltamethrin on haematological indices of common carp (Cyprinus carpio L.). Acta Vet. Brno. 72:79-85.
Szegletes T, Balint T, Szegletes Z, Nemcsok J (1995). In vivo effects of deltamethrin exposure on activity and distribution of molecular forms of carp AchE, Ecotoxicol. Environ. Saf. 31 (3):258-263.

Tinoco-Ojanguren R, Halperin DC (1998). Poverty, production health: inhibition of erythrocyte cholinesterase via occupational exposure to organophosphate insecticides in Chiapas, Mexico. Arch. Environ Health 53:29-35.

Ural MS, Sağlam N (2005). A study on the acute toxicity of pyrethroid deltamethrin on the fry rainbow trout (Oncorhynchus mykiss Walbaum, 1792). Pest. Biochem. Physiol. 83:124-131.

Vale JA (1998). Toxicokinetic and toxicodynamic aspects of organophosphorus (OP) insecticide poisoning. Toxicol. Lett. 102-103:649652.

Villarini M, Moretti M, Pasquini R, Scassellati- Sforzolini, G, Fatigoni, C, Silvano Monarca MM, Rodriguez AV (1998). In vitro genotoxic effects of the insecticide deltamethrin in human peripheral blood leukocytes: DNA damage ('comet assay') in relation to the induction of sisterchromatid exchanges and micronuclei. Toxicology 130:129-139.

Viran R, Erkoç FÜ, Polat H, Koçak Ö (2003). Investigation of acute toxicity of deltamethrin on guppies (Poecilia reticulata). Ecotoxicol. Environ. Saf. 55:82-85.

Vostradovsky J (1973). Freshwater fishes. The Hamlyn Publishing Group Limited, London. P. 252.

Worthing CR (ed.) (1983). The Pesticide Manual: A World Compendium. Seventh edition. British Crop Protection Council. The Laveham Press Ltd., Lavenham. P 337. 